\title{
Expression of Lipolytic Genes in Adipose Tissue Is Differentially Regulated During Multiple Phases of Dietary Intervention in Obese Women
}

\author{
K. KOPPO ${ }^{1,2}$, C. VALLE ${ }^{3,4}$, M. ŠIKLOVÁ-VÍTKOVÁ ${ }^{1,3}$, E. CZUDKOVÁ ${ }^{1}$, \\ I. DE GLISEZINSKI ${ }^{3,4,5}$, J. VAN DE VOORDE ${ }^{2}$, D. LANGIN ${ }^{3,4,6}$, V. ŠTICH ${ }^{1,3}$
}

${ }^{1}$ Department of Sports Medicine, Third Faculty of Medicine, Charles University, Prague, Czech Republic, ${ }^{2}$ Department of Pharmacology, Faculty of Medicine and Health Sciences, Ghent University, Ghent, Belgium, ${ }^{3}$ Franco-Czech Laboratory of Clinical Research on Obesity, INSERM and Third Faculty of Medicine of the Charles University, Prague, Czech Republic, ${ }^{4}$ Laboratoire de Recherches sur les Obésités, Institut des Maladies Métaboliques et Cardiovasculaires (I2MC), UMR 1048 Inserm, Université Paul Sabatier, Toulouse, France, ${ }^{5}$ Department of Sports Medicine, CHU Toulouse, France, ${ }^{6}$ Department of Clinical Biochemistry, CHU Toulouse, France

Received November 15, 2012

Accepted June 7, 2013

On-line September 10, 2013

\section{Summary}

The aim of this study was to investigate the time-course of the expression of key lipolysis-regulating genes in the subcutaneous adipose tissue (SCAT) during different phases of a 6-month dietary intervention. Fifteen obese women (BMI $34.7 \pm 1.0 \mathrm{~kg} \cdot \mathrm{m}^{-2}$ ) underwent a 6-month dietary intervention consisting of 1 month very low calorie diet (VLCD), followed by 2 months low calorie diet (LCD) and 3 months weight maintenance diet (WM). At each phase of the dietary intervention, a needle microbiopsy of the abdominal SCAT was obtained to evaluate mRNA expression of key lipolysisregulating genes and a hyperinsulinemic euglycemic clamp (HEC) was performed. Dietary intervention induced a body weight reduction of $9.8 \%$ and an improvement of insulin sensitivity as assessed by a HEC. Compared to pre-diet levels, mRNA levels of the adrenergic $\beta_{2}$-receptor in SCAT were higher at the end of VLCD and not different at the end of LCD and WM. In contrast, the expression of the adrenergic $a_{2}$-receptor was lower at the end of VLCD and LCD compared to the prediet levels and did not differ at WM. Adipose triglyceride lipase and hormone-sensitive lipase levels were lower than the prediet levels at the end of LCD only, while phosphodiesterase-3B and the insulin receptor levels did not change throughout the dietary intervention. The results suggest that the regulation pattern of the genes that are involved in the control of lipolysis is different at the respective phases of the dietary intervention and depends on the duration of the diet and the status of energy balance.

\section{Key words}

Insulin • Adipocytes • Hypocaloric diet

\section{Corresponding author}

K. Koppo, Department of Sports Medicine, Third Faculty of Medicine, Charles University of Prague, Ruská 87, 10000 Prague 10, Czech Republic. Fax: +420 267102 263. E-mail: katrien.koppo@gmail.com

\section{Introduction}

Traditional weight-reducing hypocaloric diets as well as bariatric surgery interventions lead to an improvement in metabolic status of obese subjects already during the early stages of the intervention. It has been suggested that the early improvement in metabolic status is associated with calorie restriction per se eventually combined with a mild initial weight loss while the later beneficial metabolic effects are linked to sustained weight loss only (Hensrud 2001, Gumbs et al. 2005). Adipose tissue lipolysis has been suggested as one 
of the candidate mechanisms underlying the obesityrelated metabolic disturbances, namely insulin resistance (Reynisdottir et al. 1994a,b). Moreover, impaired catecholamine-mediated lipolysis was demonstrated in first-degree relatives of obese subjects (Hellström et al. 1996a) which suggests an association between blunted catecholamine-induced lipolysis and excessive accumulation of body fat.

Therefore, in the present study we aimed to follow the evolution of whole-body insulin sensitivity and the evolution of expression of genes involved in lipolysis regulation in adipose tissue (AT) during a dietary intervention (DI) which consisted of multiple phases. The first phase of the diet consisted of one month severe calorie restriction using a very low calorie diet (VLCD) of $3000 \mathrm{~kJ} / \mathrm{d}$. The subsequent phase consisted of 2 months low calorie diet (LCD) with a calorie intake of $5000-6000 \mathrm{~kJ}$, followed by a 3 month weight maintenance diet (WM). This model provides an opportunity to study the "lipolysis - metabolic status energy status" relationship.

Previous studies that reported mRNA data of genes involved in lipolysis regulation in AT during dietary interventions yielded various results, possibly related to differences in duration and severity of the diet as well as to the characteristics of the study populations. For example, the mRNA and protein levels of hormonesensitive lipase (HSL) in subcutaneous AT (SCAT) of obese subjects were reduced after 8-12 weeks of diet (Reynisdottir et al. 1995, Jocken et al. 2007), while no differences or an increase in the HSL protein level were reported for dietary interventions with a shorter duration (4 weeks of VLCD) (Hellström et al. 1996b, Stich et al. 1997). Capel et al. (2009) showed that the regulation of adipocyte and macrophage genes during a multi-phase diet was dependent on the phase of the diet, namely the metabolism-related genes predominantly expressed in adipocytes were downregulated during energy restriction and upregulated during weight stabilization, while the genes related to immune functions that were predominantly expressed in macrophages were not changed or upregulated during energy restriction and downregulated during weight stabilization. Similar results were demonstrated regarding the regulation of lipolysis in situ: in obese women it was shown that the responsiveness of SCAT to adrenergic regulation of lipolysis varied during the respective phases of the diet (Koppo et al. 2012).

In the present study, we explored the lipolysis regulation at the transcriptional level and measured mRNA expression of key lipolytic genes in needle biopsy-derived samples of SCAT in a group of obese women that followed the above mentioned multiplephase dietary intervention. In each individual, the SCAT samples were obtained at baseline and at the end of each dietary phase. At each phase of the diet, the wholebody insulin sensititivity was measured using a hyperinsulinemic euglycemic clamp. We demonstrated that the lipolysis is regulated at the transcriptional level during a multiple-phase dietary intervention and that the regulation during the early phase of the diet differs from that during the later periods. No straightforward relationship between the evolution of gene expression and that of insulin sensitivity was found.

\section{Methods}

\section{Subjects}

Fifteen obese premenopausal women were recruited for the study (Table 1). They all had a stable weight during the 3 months that preceded the study. Exclusion criteria were hypertension, diabetes, hyperlipidemia treated by drugs, drug-treated obesity, drug or alcohol abuse, pregnancy or participation in other studies. All subjects were fully informed about the aim and the protocol of the study and signed an informed consent approved by the Ethics committee of the Third Faculty of Medicine of the Charles University (Prague, Czech Republic).

\section{Dietary intervention}

During the first month of the dietary intervention program, subjects received a $3000 \mathrm{~kJ} / \mathrm{d}$ VLCD (liquid formula diet; Redita, Promil, Czech Republic). During the next 2 months, a LCD was designed to provide $2500 \mathrm{~kJ} / \mathrm{d}$ less than the individually estimated energy requirement based on an initial resting metabolic rate multiplied by 1.3 (the coefficient of correction for physical activity level; Toubro et al. 1996.). The final 3 months consisted of a WM diet during which subjects kept a stable weight. Subjects consulted a dietician once a week during the first 3 months and once a month during the WM phase. They provided a written 3-days dietary record at each consultation. Subjects were instructed not to change the level of their leisure time physical activity during the intervention. This was monitored by selfreported questionnaires. 
Table 1. Subjects' characteristics.

\begin{tabular}{|c|c|c|c|c|}
\hline & Pre-diet & VLCD & LCD & WM \\
\hline Weight (kg) & $94.9 \pm 3.4$ & $87.9 \pm 3.2^{\mathrm{a}}$ & $85.2 \pm 3.2^{\mathrm{a}, \mathrm{b}}$ & $85.6 \pm 3.2^{\mathrm{a}, \mathrm{b}}$ \\
\hline$B M I\left(\mathrm{~kg} / \mathrm{m}^{2}\right)$ & $34.7 \pm 1.0$ & $32.1 \pm 1.0^{\mathrm{a}}$ & $31.1 \pm 1.0^{\mathrm{a}, \mathrm{b}}$ & $31.3 \pm 1.0^{\mathrm{a}, \mathrm{b}}$ \\
\hline Fat mass (kg) & $38.2 \pm 2.7$ & $32.7 \pm 2.4^{\mathrm{a}}$ & $29.7 \pm 2.0^{\mathrm{a}, \mathrm{b}}$ & $30.6 \pm 2.4^{\mathrm{a}}$ \\
\hline Fat free mass $(\mathrm{kg})$ & $56.8 \pm 1.4$ & $55.2 \pm 1.5^{\mathrm{a}}$ & $55.6 \pm 1.7$ & $55.1 \pm 1.5^{\mathrm{a}}$ \\
\hline Waist circumference $(\mathrm{cm})$ & $102.9 \pm 3.1$ & $97.2 \pm 3.3^{\mathrm{a}}$ & $95.4 \pm 3.3^{\mathrm{a}, \mathrm{b}}$ & $95.1 \pm 3.2^{\mathrm{a}, \mathrm{b}}$ \\
\hline Cholesterol $(\mathrm{mmol} / \mathrm{l})$ & $4.8 \pm 0.1$ & $3.9 \pm 0.2^{\mathrm{a}}$ & $4.3 \pm 0.2^{\mathrm{a}, \mathrm{b}}$ & $4.6 \pm 0.2^{b}$ \\
\hline HDL cholesterol (mmol/l) & $1.10 \pm 0.09$ & $0.94 \pm 0.07^{\mathrm{a}}$ & $1.12 \pm 0.08^{b}$ & $1.22 \pm 0.06^{\mathrm{a}, \mathrm{b}, \mathrm{c}}$ \\
\hline Triglycerides (mmol/l) & $1.57 \pm 0.21$ & $1.12 \pm 0.10^{\mathrm{a}}$ & $1.11 \pm 0.10^{\mathrm{a}}$ & $1.07 \pm 0.06^{\mathrm{a}}$ \\
\hline Glycerol $(\mu \mathrm{mol} / \mathrm{l})$ & $222 \pm 21$ & $157 \pm 10^{\mathrm{a}}$ & $140 \pm 17^{\mathrm{a}}$ & $142 \pm 12^{\mathrm{a}}$ \\
\hline NEFAs $(\mu \mathrm{mol} / \mathrm{l})$ & $653 \pm 45$ & $684 \pm 46$ & $553 \pm 50^{\mathrm{a}, \mathrm{b}}$ & $515 \pm 53^{\mathrm{a}, \mathrm{b}}$ \\
\hline Fasting glucose ( $\mathrm{mmol} / \mathrm{l})$ & $5.6 \pm 0.1$ & $5.4 \pm 0.2$ & $5.5 \pm 0.1$ & $5.3 \pm 0.2$ \\
\hline Fasting insulin (mU/l) & $12.4 \pm 2.0$ & $6.7 \pm 0.6^{\mathrm{a}}$ & $5.6 \pm 0.6^{\mathrm{a}}$ & $7.3 \pm 0.7^{\mathrm{a}, \mathrm{c}}$ \\
\hline GDR (mg/kg.min) & $3.1 \pm 0.4$ & $3.9 \pm 0.5^{\mathrm{a}}$ & $4.3 \pm 0.5^{\mathrm{a}}$ & $4.3 \pm 0.4^{\mathrm{a}}$ \\
\hline
\end{tabular}

BMI: body mass index, HDL: high-density lipoprotein, NEFAs: non-esterified fatty acids and GDR: glucose disposal rate normalized to kg of body weight. $^{a}=$ significantly different from pre-diet values $(P<0.05),{ }^{b}=$ significantly different from VLCD $(P<0.05),{ }^{c}=$ significantly different from LCD $(P<0.05)$.

\section{Experimental protocol}

On four occasions (i.e. before the start of the dietary intervention (baseline) and at the end of the VLCD, LCD and WM phase, respectively) subjects entered the laboratory at 8.00 a.m. after an overnight fast. A complete clinical investigation was performed, anthropometric parameters were measured and body composition was determined with multifrequency bioimpedance (Bodystat QuadScan 4000; Bodystat Ltd., Isle of Man, British Isles). Subsequently, subjects were placed in a semi-recumbent position. Venous blood samples were taken from an antecubital vein in order to determine the blood parameters related to lipid and carbohydrate metabolism. A needle microbiopsy of the abdominal SCAT (14-20 cm lateral to the umbilicus) was performed under local anesthesia (1\% Xylocaine; AstraZeneca PLC, London, UK) as previously described (Klimcakova et al. 2006) to evaluate mRNA of key genes that are involved in SCAT lipolysis regulation. The samples were frozen immediately in liquid nitrogen and stored at $-80{ }^{\circ} \mathrm{C}$ until analysis. Finally, a 3-h hyperinsulinemic euglycemic clamp (HEC) was performed to determine the glucose disposal rate.

\section{Hyperinsulinemic euglycemic clamp}

HEC was performed according to the DeFronzo method (DeFronzo et al. 1979). Priming plus continuous infusion of crystalline human insulin (Actrapid Human;
Novo, Bagsvaerd, Denmark), $40 \mathrm{mU} / \mathrm{m}^{2}$ body area $\mathrm{min}$, was given for $180 \mathrm{~min}$. Euglycemia (the fasting blood glucose concentration) was maintained by a variable $20 \%$ glucose infusion. The infusion rate was determined by measuring arterialized plasma glucose every $5 \mathrm{~min}$ (Beckman Glucose Analyzer; Beckman Coulter Inc., Fullerton, CA, USA).

\section{Quantification of $m R N A$ analysis}

Total RNA was extracted from the adipose tissue biopsy samples with an RNeasy Mini kit (Qiagen, Valencia, CA) and reverse transcribed using random hexamers (Promega Corp., Madison, WI) and SuperScript II Reverse Transcriptase (Invitrogen Corp., Carlsbad, CA). Real-time quantitative PCR was performed with TaqMan probe-based gene expression assays (Applied Biosystems, Foster City, CA). An 18S ribosomal RNA was used as control to normalize gene expression (Ribosomal RNA Control TaqMan Assay kit; Applied Biosystems). Each sample was performed in duplicate and $10 \mathrm{ng}$ cDNA was used as a template for real-time PCR. The relative expression was calculated using the $\Delta \Delta \mathrm{Ct}$ method (Livak and Schmittgen 2001).

\section{Drugs and biochemical determinations}

Plasma glucose was determined with a glucose hexokinase technique (Konelab 60i, Labsystems CLD, Konelab, Finland). Plasma insulin concentrations were 
Table 2. Expression of lipolytic genes before and during the respective phases of the multi-dietary intervention.

\begin{tabular}{lllll}
\hline & Pre-diet & VLCD & LCD & WM \\
\hline ADRA2A & $0.079 \pm 0.008$ & $0.058 \pm 0.008^{\mathrm{a}}$ & $0.050 \pm 0.005^{\mathrm{a}}$ & $0.065 \pm 0.008$ \\
$A D R B 2$ & $0.17 \pm 0.01$ & $0.21 \pm 0.02^{\mathrm{a}}$ & $0.19 \pm 0.01$ & $0.18 \pm 0.01$ \\
PDE3B & $0.94 \pm 0.06$ & $0.82 \pm 0.07$ & $0.87 \pm 0.06$ & $0.87 \pm 0.05$ \\
$I N S R$ & $0.57 \pm 0.04$ & $0.63 \pm 0.04$ & $0.62 \pm 0.04$ & $0.63 \pm 0.03$ \\
$H S L$ & $4.71 \pm 0.29$ & $4.53 \pm 0.29$ & $4.11 \pm 0.31^{\mathrm{a}}$ & $4.31 \pm 0.20$ \\
$A T G L$ & $4.15 \pm 0.23$ & $3.61 \pm 0.24 *$ & $3.67 \pm 0.20^{\mathrm{a}}$ & $3.99 \pm 0.16$ \\
\hline
\end{tabular}

ADRA2A: adrenergic $a_{2 A}$-receptor, ADRB2: adrenergic $\beta_{2}$-receptor, PDE3B: phosphodiesterase-3B, INSR: insulin receptor, HSL: hormone-sensitive lipase and ATGL: adipose triglyceride lipase. Values shown in the table represent mRNA levels ( $\left.\times 10^{4}\right)$. ${ }^{a}=$ significantly different from pre-diet values $(P<0.05), * p=0.076$.

measured using a chemiluminescent immunometric assay (Immulite 2000 Insulin, DPC Czech sro, Brno, Czech Republic). Other laboratory analyses (lipids) were performed using standard biochemical laboratory methods.

\section{Statistical analysis}

All values are presented as means \pm SEM. Statistical evaluation of the data was performed using ANOVA for repeated measures with an LSD post-hoc test (SPSS statistical software, version 19, SPSS Inc, Chicago). Correlations between mRNA gene expression and the diet-induced change in body fat mass were examined with the Pearson correlation coefficient. Significance was determined at $\mathrm{P}<0.05$.

\section{Results}

Anthropometric and plasma parameters of subjects during the different phases of the diet

Pre-diet values and values measured at different phases during the weight reduction program (i.e. at the end of VLCD, LCD and WM) are reported in Table 1. Subjects' body weight progressively decreased during VLCD and LCD and stabilized during WM. The loss in body weight was mainly due to a decrease in fat mass. Plasma triglycerides were significantly lower at the end of VLCD, LCD and WM compared to the pre-diet values. Similarly, baseline insulin levels were significantly lower at the end of VLCD, LCD and WM (Table 1). The glucose disposal rate (GDR) normalized to body weight significantly increased at the end of VLCD and the increase was maintained at the end of LCD and WM (Table 1).

\section{Effect of the dietary intervention on gene expression}

SCAT mRNA levels of key genes involved in adipose tissue lipolysis regulation, i.e. the adrenergic $\beta_{2}$ receptor (ADRB2), adrenergic $\alpha_{2 \mathrm{~A}}$-receptor (ADRA2A), adipose triglyceride lipase (ATGL), hormone-sensitive lipase (HSL), phosphodiesterase-3B (PDE3B) and insulin receptor (INSR), were quantified (Table 2). ADRB2 expression significantly increased at the end of VLCD when compared with the pre-diet baseline level and then, at the end of LCD and WM, returned to the pre-diet baseline levels. The expression of ADRA2A was significantly lower at the end of VLCD and LCD compared to the pre-diet baseline and increased back towards the pre-diet levels during WM. Expression of PDE3B and INSR did not significantly change throughout the intervention. The diet-induced adaptation of HSL and ATGL was similar: mRNA levels of the two lipases were significantly lower at the end of LCD compared with pre-diet levels and returned to the pre-diet levels at the end of WM. At the end of VLCD, ATGL levels were lower than the pre-diet levels but the difference was not significant $(\mathrm{P}=0.076)$.

Associations between the diet-induced changes of clinical variables and $m R N A$ levels

No significant correlations between the pre-diet baseline mRNA expression of the genes explored and the diet-induced change in body fat mass during VLCD were observed: $r=0.076$ for ADRA2A, $r=-0.159$ for ADRB2, $r=-0.001$ for PDE3B, $r=-0.147$ for INSR, $r=-0.266$ for HSL and $r=-0.174$ for ATGL. Similarly, no significant correlations between the pre-diet baseline mRNA expression of the genes and the diet-induced change in body fat mass during the entire 6-month intervention were observed: $r=-0.018$ for ADRA2A, 
$\mathrm{r}=0.064$ for ADRB2, $\mathrm{r}=0.052$ for PDE3B, $r=-0.060$ for INSR, $r=-0.056$ for HSL and $r=-0.004$ for ATGL. When attention was paid to the predictive power of the diet-induced changes of mRNA levels during the early phase of the intervention (VLCD), no significant correlations were found between VLCD-induced changes of mRNA levels of the respective genes and the dietinduced reduction of body fat mass either during VLCD $(r=0.278$ for ADRA2A, $r=0.192$ for ADRB2, $r=0.240$ for PDE3B, $r=0.073$ for INSR, $r=0.143$ for HSL and $r=0.147$ for ATGL) or during the entire 6-month intervention $(\mathrm{r}=-0.085$ for ADRA2A, $\mathrm{r}=-0.101$ for ADRB2, $r=-0.128$ for PDE3B, $r=-0.304$ for INSR, $r=-0.254$ for HSL and $r=-0.200$ for ATGL).

\section{Discussion}

Results of the present study demonstrate that multi-phase dietary intervention modifies the expression of key genes involved in SCAT lipolysis control and that the status of energy balance during the dietary intervention is an important determinant of the lipolysis genes regulation. These findings are in agreement with previous research in humans (Vitkova et al. 2007, Capel et al. 2009, Kováčiková et al. 2010) and in experimental models (Kosteli et al. 2010) that showed that the dietinduced changes of adipose tissue expression of genes related to metabolism or immune function are strongly dependent on the phase of the diet.

One of the regulators of lipolysis that received substantial attention in dietary intervention studies are catecholamines as they are believed to be one of the major players that regulate lipid mobilization in adipose tissue. Most of the studies that examined the lipolytic response to $\beta$-adrenergic stimulation after 3-12 weeks VLCD reported an increased lipolytic response in situ (Barbe et al. 1997, Flechtner-Mors et al. 1999, Sengenes et al. 2002) and in vitro (Stich et al. 1997, Wahrenberg et al. 1999). After 15-weeks LCD, the maximal lipolytic response to isoprenaline (a $\beta$-adrenoreceptor agonist) was unchanged when compared to the pre-diet level, while the $\beta$-adrenoreceptor lipolytic sensitivity was increased in isolated adipocytes (Mauriège et al. 1999). The $\alpha_{2}$-adrenoceptor mediated anti-lipolytic action in isolated adipocytes was found to be unchanged after 4-12 weeks VLCD (Kather et al. 1985, Stich et al. 1997, Wahrenberg et al. 1999) and to be reduced after 12-15 weeks LCD in vitro (Mauriège et al. 1999) and in situ (Stich et al. 2002). Results of the above mentioned single-phase dietary intervention studies were in agreement with a recent study in which the SCAT lipolysis was examined during a long-term multi-phase diet (Koppo et al. 2012). The authors reported that the adrenaline-induced SCAT lipolysis in vivo was enhanced during the calorierestricted phases of the diet and returned back to the prediet levels during the WM phase. The diet-induced changes in SCAT lipolysis were rather related to a decreased $\alpha_{2}$-adrenergic regulation than to an increased $\beta$-adrenergic regulation (Koppo et al. 2012). Changes in postreceptor signaling pathways as well as changes in density of the adrenoceptors should be considered as possible mechanisms that underlie the changes in lipolytic responsiveness during the dietary intervention. It was found that in SCAT of obese women the $\beta$-adrenoreceptor density increased after VLCD compared with the pre-diet levels, while the $\alpha_{2}$ adrenoreceptor density remained unchanged (Mauriège $e t$ al. 1999, Wahrenberg et al. 1999). On the transcriptional level, it was reported that, after 12 weeks of LCD, SCAT ADRA2A mRNA levels decreased and ADRB2 mRNA levels did not change compared with the pre-diet condition in obese women (Stich et al. 2002). The present study investigated the changes in adrenoceptor gene expression during different phases of the dietary intervention in the same individual. The lipolytic ADRB2 gene was up-regulated after VLCD, and not after LCD and WM, while the anti-lipolytic ADRA2A gene was down-regulated after VLCD and LCD. After WM, the adrenoceptor mRNA levels returned back to the pre-diet values. Although there are many intermediate steps between the adrenergic regulation of SCAT lipolysis in vivo and the transcriptional level of the adrenoceptor gene expression, these findings parallel the results of our previous study mentioned above (Koppo et al. 2012) in which adrenergic regulation of lipolysis was investigated in situ using microdialysis. Indeed, in that study, the $\alpha_{2}$-mediated antilipolytic action was reduced in situ at VLCD and LCD, similarly to the evolution of ADRA2A mRNA levels. In contrast, the $\beta$-adrenoceptor-mediated stimulation of lipolysis in situ increased at VLCD and went back to pre-diet levels, similarly to ADRB2 mRNA levels.

Another important lipolysis-regulating pathway is that of insulin. In the present study mRNA levels of PDE3B and INSR were explored. The anti-lipolytic effect of insulin is mediated through activation of PDE3B; more specifically, insulin activates phosphatidylinositol 3-kinase serine kinase, the kinase that activates PDE3B, 
through binding to INSR (Rondinone et al. 2000). The activation of PDE3B promotes cAMP degradation, which in turn inactivates protein kinase A (PKA) that reduces phosphorylation of lipases and perilipins. In the present study, no changes in mRNA levels of PDE3B and INSR were observed throughout the dietary intervention. It cannot be excluded that a change in the activation of PDE3B might have occurred. Nevertheless, in situ data also suggest a lack of change in insulin sensitivity of adipose tissue during this dietary intervention: it was reported that, during a hyperinsulinemic euglycemic clamp performed at different time points of a multi-phase diet, the decrease in SCAT dialysate glycerol was similar at the respective phases of the diet. This demonstrated that the anti-lipolytic effect of insulin did not change throughout the dietary intervention during which subjects' whole-body insulin sensitivity improved (Koppo et al. 2012).

In the present study we also focused on the two lipases that are involved in the lipolytic pathway. ATGL and HSL are cytosol lipases that hydrolyze intracellular triacylglycerols (TAGs) into glycerol and NEFA. HSL has been considered to be the enzyme that catalyzes the rate-limiting step of adipose tissue lipolysis. However, more recently it was reported that the overexpression of ATGL may increase basal lipolysis while its inhibition suppresses stimulated lipolysis (Bezaire et al. 2009). Regarding the factors that influence HSL gene expression, it was reported that glucose deprivation (Raclot et al. 1998) as well as a sustained activation of the PKA pathway (Plée-Gautier et al. 1996) downregulated the HSL gene. Taking into account that during the calorie-restricted phases of the diet, glucose intake is limited and the stimulated SCAT lipolysis (and thus the activation of the PKA pathway) is enhanced, it can be hypothesized that the HSL gene would be down-regulated during the calorie-restricted phases. Indeed, mRNA levels of HSL were significantly lower at the end of LCD $\left(12^{\text {th }}\right.$ week of diet) compared with pre-diet levels, but no changes were observed at the end of VLCD $\left(4^{\text {th }}\right.$ week of diet). In accordance with these findings, the HSL mRNA and protein levels in SCAT of obese subjects were reduced after 8-12 weeks of different types of diet (Reynisdottir et al. 1995, Jocken et al. 2007), while no differences or an increase in HSL protein level were reported for dietary interventions with a shorter duration (4 weeks of VLCD) (Hellström et al. 1996b, Stich et al. 1997). The duration of the calorie restriction seems to play an important role in the regulation of the lipase expression. Similarly to HSL, ATGL mRNA and protein level were shown to be decreased in SCAT of obese subjects that had followed a 10 week low-fat or mediumfat diet (Jocken et al. 2007). Also in the present study, mRNA levels of ATGL were significantly lower at the end of LCD compared with pre-diet levels. Interestingly, the pattern of evolution of ATGL mRNA levels during this dietary intervention paralleled the evolution of basal lipolysis in situ observed in our previous microdialysis study (Koppo et al. 2012). In contrast, no such parallel was found for the pattern of evolution of mRNA HSL: it was different when compared with either basal lipolysis or adrenaline-stimulated lipolysis in situ.

As mentioned above, results of this study and of previous ones show that the diet-induced changes of adipose tissue gene expression are dependent on the phase of the diet. Capel et al. (2009) showed that the regulation of adipocyte and macrophage genes during a multi-phase diet was dependent on the phase of the diet. The metabolism-related genes (predominantly expressed in adipocytes) were downregulated during energy restriction and upregulated during weight stabilization, while the genes related to immune functions (predominantly expressed in macrophages) were not changed or upregulated during energy restriction and downregulated during weight stabilization (Capel et al. 2009). Furthermore, recent studies showed the dependence of lipolysis on the phase of the hypocaloric diet in mice (Kosteli et al. 2010) and in humans (Koppo et al. 2012). In the former study (Kosteli et al. 2010) it was suggested that lipolysis drives the adipose tissue macrophage accumulation since the peak in macrophage number coincided with the peak in adipose tissue lipolysis. Furthermore, after an extended period of weight loss, adipose tissue lipolysis decreased, as did the macrophage content. It would be tempting to hypothesize that the same regulatory effect could occur in humans. It was reported that markers of macrophage infiltration in human SCAT show a similar time-pattern, i.e. a slight or no increase during one month of VLCD and a decrease under the pre-diet levels at the end of a 6 month diet (Capel et al. 2009, Kováčiková et al. 2010). This would suggest that the biological role of SCAT lipolysis goes beyond serving as an energy substrate and that it may play a role in the regulation of macrophage infiltration and the inflammation of the adipose tissue.

Similarly to the studies of Mutch et al. (2007, 2011) it might be hypothesized that the baseline levels of the lipolytic genes or their diet-induced changes are 
predictors of the diet-induced loss in fat mass. We tested specifically whether subjects with higher "responsiveness", i.e. larger modifications of mRNA levels of the respective genes during the initial phase of the diet (i.e. VLCD), would be those with higher dietinduced fat loss either during VLCD or during the entire 6-month intervention. This association was not confirmed in the present study. Similarly, no associations between the pre-diet mRNA expression of lipolysis-regulating genes and the diet-induced loss in fat mass during either VLCD or entire intervention were observed.

In conclusion, this study demonstrates that the dietary intervention associated with an improvement in insulin sensitivity modifies the mRNA expression of key genes that are involved in SCAT lipolysis regulation. The pattern of this diet-induced modification varies during the course of the diet and is related to the status of energy balance. No straightforward relationship between the evolution of expression of the respective genes and that of insulin sensitivity was found.

\section{Conflict of Interest}

There is no conflict of interest.

\section{Acknowledgements}

This study was supported by grant IGA NT 11450-3/2010 of the Ministry of Health of Czech Republic, by a grant from the Direction Générale de la Coopération Internationale et du Développement (Programme d'Action Intégré Franco-Tchèque), by a grant from Novartis Pharma S.A.S, by the grant of the Ministry of Education of Czech Republic MSM 0021620814, and by Integrated Project HEPADIP (www.hepadip.org), (Contract No. LSHM-CT-2005-018734) and Collaborative Project ADAPT (www.adapt-eu.net), (Contract No. HEALTH-F2-2008-2011 00). K. Koppo was supported by a postdoctoral research grant from the Special Research Fund of the Ghent University. We are indebted to Zuzana Parizkova for her technical expertise.

\section{References}

BARBE P, STICH V, GALITZKY J, KUNESOVA M, HAINER V, LAFONTAN M, BERLAN M: In vivo increase in beta-adrenergic lipolytic response in subcutaneous adipose tissue of obese subjects submitted to a hypocaloric diet. J Clin Endocrinol Metab 82: 63-69, 1997.

BEZAIRE V, MAIRAL A, RIBET C, LEFORT C, GIROUSSE A, JOCKEN J, LAURENCIKIENE J, ANESIA R, RODRIGUEZ AM, RYDEN M, STENSON BM, DANI C, AILHAUD G, ARNER P, LANGIN D: Contribution of adipose triglyceride lipase and hormone-sensitive lipase to lipolysis in hMADS adipocytes. J Biol Chem 284: 18282-18291, 2009.

CAPEL F, KLIMCÁKOVÁ E, VIGUERIE N, ROUSSEL B, VÍTKOVÁ M, KOVÁCIKOVÁ M, POLÁK J, KOVÁCOVÁ Z, GALITZKY J, MAORET JJ, HANÁCEK J, PERS TH, BOULOUMIÉ A, STICH V, LANGIN D: Macrophages and adipocytes in human obesity: adipose tissue gene expression and insulin sensitivity during calorie restriction and weight stabilization. Diabetes 58: 1558-1567, 2009.

DEFRONZO RA, TOBIN JD, ANDRES R: Glucose clamp technique: a method for quantifying insulin secretion and resistance. Am J Physiol 237: E214-E223, 1979.

FLECHTNER-MORS M, DITSCHUNEIT HH, YIP I, ADLER G: Sympathetic modulation of lipolysis in subcutaneous adipose tissue: effects of gender and energy restriction. J Lab Clin Med 134: 33-41, 1999.

GUMBS AA, MODLIN IM, BALLANTYNE GH: Changes in insulin resistance following bariatric surgery: role of caloric restriction and weight loss. Obes Surg 15: 462-473, 2005.

HELLSTRÖM L, LANGIN D, REYNISDOTTIR S, DAUZATS M, ARNER P: Adipocyte lipolysis in normal weight subjects with obesity among first-degree relatives. Diabetologia 39: 921-928, 1996a.

HELLSTRÖM L, REYNISDOTTIR S, LANGIN D, RÖSSNER S, ARNER P: Regulation of lipolysis in fat cells of obese women during long-term hypocaloric diet. Int J Obes Relat Metab Disord 20: 745-752, $1996 \mathrm{~b}$.

HENSRUD DD: Dietary treatment and long-term weight loss and maintenance in type 2 diabetes. Obes Res 9: 348S-353S, 2001.

JOCKEN JW, LANGIN D, SMIT E, SARIS WH, VALLE C, HUL GB, HOLM C, ARNER P, BLAAK EE: Adipose triglyceride lipase and hormone-sensitive lipase protein expression is decreased in the obese insulin-resistant state. J Clin Endocrinol Metab 92: 2292-2299, 2007. 
KATHER H, WIELAND E, FISCHER B, WIRTH A, SCHLIERF G: Adrenergic regulation of lipolysis in abdominal adipocytes of obese subjects during caloric restriction: reversal of catecholamine action caused by relief of endogenous inhibition. Eur J Clin Invest 15: 30-37, 1985.

KLIMCAKOVA E, POLAK J, MORO C, HEJNOVA J, MAJERCIK M, VIGUERIE N, BERLAN M, LANGIN D, STICH V: Dynamic strength training improves insulin sensitivity without altering plasma levels and gene expression of adipokines in subcutaneous adipose tissue in obese men. J Clin Endocrinol Metab 91: 51075112, 2006.

KOPPO K, SIKLOVÁ-VITKOVÁ M, KLIMCÁKOVÁ E, POLÁK J, MARQUES MA, BERLAN M, VAN DE VOORDE J, BULOW J, LANGIN D, DE GLISEZINSKI I, STICH V: Catecholamine and insulin control of lipolysis in subcutaneous adipose tissue during long-term diet-induced weight loss in obese women. $A m J$ Physiol Endocrinol Metab 302: E226-E232, 2012.

KOSTELI A, SUGARU E, HAEMMERLE G, MARTIN JF, LEI J, ZECHNER R, FERRANTE AW JR: Weight loss and lipolysis promote a dynamic immune response in murine adipose tissue. J Clin Invest 120: 3466-3479, 2010.

KOVÁČIKOVÁ M, SENGENES C, KOVÁČOVÁ Z, SIKLOVÁ-VÍTKOVÁ M, KLIMČÁKOVÁ E, POLÁK J, ROSSMEISLOVÁ L, BAJZOVÁ M, HEJNOVÁ J, HNĚVKOVSKÁ Z, BOULOUMIÉ A, LANGIN D, STICH V: Dietary intervention-induced weight loss decreases macrophage content in adipose tissue of obese women. Int J Obes (Lond) 35: 91-98, 2010.

LIVAK KJ, SCHMITTGEN TD: Analysis of relative gene expression data using real-time quantitative PCR and the 2(Delta Delta C(T)) Method. Methods 25: 402-408, 2001.

MAURIÈGE P, IMBEAULT P, LANGIN D, LACAILLE M, ALMÉRAS N, TREMBLAY A, DESPRÉS JP: Regional and gender variations in adipose tissue lipolysis in response to weight loss. J Lipid Res 40: 1559-1571, 1999.

MUTCH DM, TEMANNI MR, HENEGAR C, COMBES F, PELLOUX V, HOLST C, SØRENSEN TI, ASTRUP A, MARTINEZ JA, SARIS WH, VIGUERIE N, LANGIN D, ZUCKER JD, CLÉMENT K: Adipose gene expression prior to weight loss can differentiate and weakly predict dietary responders. PLoS One 2: e1344, 2007.

MUTCH DM, PERS TH, TEMANNI MR, PELLOUX V, MARQUEZ-QUIÑONES A, HOLST C, MARTINEZ JA, BABALIS D, VAN BAAK MA, HANDJIEVA-DARLENSKA T, WALKER CG, ASTRUP A, SARIS WH, LANGIN D, VIGUERIE N, ZUCKER JD, CLÉMENT K, DIOGENES PROJECT: A distinct adipose tissue gene expression response to caloric restriction predicts 6-mo weight maintenance in obese subjects. Am J Clin Nutr 94: 1399-1409, 2011.

PLÉE-GAUTIER E, GROBER J, DUPLUS E, LANGIN D, FOREST C: Inhibition of hormone-sensitive lipase gene expression by cAMP and phorbol esters in 3T3-F442A and BFC-1 adipocytes. Biochem J 318: 1057-1063, 1996.

RACLOT T, DAUZATS M, LANGIN D: Regulation of hormone-sensitive lipase expression by glucose in 3T3-F442A adipocytes. Biochem Biophys Res Commun 245: 510-513, 1998.

REYNISDOTTIR S, ELLERFELDT K, WAHRENBERG H, LITHELL H, ARNER P: Multiple lipolysis defects in the insulin resistance (metabolic) syndrome. J Clin Invest 93: 2590-2599, 1994a.

REYNISDOTTIR S, WAHRENBERG H, CARLSTRÖM K, RÖSSNER S, ARNER P: Catecholamine resistance in fat cells of women with upper-body obesity due to decreased expression of beta 2-adrenoceptors. Diabetologia 37 : 428-435, 1994b.

REYNISDOTTIR S, LANGIN D, CARLSTRÖM K, HOLM C, RÖSSNER S, ARNER P: Effects of weight reduction on the regulation of lipolysis in adipocytes of women with upper-body obesity. Clin Sci (Lond) 89: 421-429, 1995.

RONDINONE CM, CARVALHO E, RAHN T, MANGANIELLO VC, DEGERMAN E, SMITH UP: Phosphorylation of PDE3B by phosphatidylinositol 3-kinase associated with the insulin receptor. J Biol Chem 275: 1009310098, 2000.

SENGENES C, STICH V, BERLAN M, HEJNOVA J, LAFONTAN M, PARISKOVA Z, GALITZKY J: Increased lipolysis in adipose tissue and lipid mobilization to natriuretic peptides during low-calorie diet in obese women. Int J Obes Relat Metab Disord 26: 24-32, 2002. 
STICH V, HARANT I, DE GLISEZINSKI I, CRAMPES F, BERLAN M, KUNESOVA M, HAINER V, DAUZATS M, RIVIÈRE D, GARRIGUES M, HOLM C, LAFONTAN M, LANGIN D: Adipose tissue lipolysis and hormone-sensitive lipase expression during very-low-calorie diet in obese female identical twins. $J$ Clin Endocrinol Metab 82: 739-744, 1997.

STICH V, MARION-LATARD F, HEJNOVA J, VIGUERIE N, LEFORT C, SULJKOVICOVA H, LANGIN D, LAFONTAN M, BERLAN M: Hypocaloric diet reduces exercise-induced alpha 2-adrenergic antilipolytic effect and alpha 2-adrenergic receptor mRNA levels in adipose tissue of obese women. $J$ Clin Endocrinol Metab 87: 1274-1281, 2002.

TOUBRO S, SORENSEN TI, RONN B, CHRISTENSEN NJ, ASTRUP A: Twenty-four-hour energy expenditure: The role of body composition, thyroid status, sympathetic activity, and family membership. $J$ Clin Endocrinol Metab 81: 2670-2674, 1996.

VITKOVA M, KLIMCAKOVA E, KOVACIKOVA M, VALLE C, MORO C, POLAK J, HANACEK J, CAPEL F, VIGUERIE N, RICHTEROVA B, BAJZOVA M, HEJNOVA J, STICH V, LANGIN D: Plasma levels and adipose tissue messenger ribonucleic acid expression of retinol-binding protein 4 are reduced during calorie restriction in obese subjects but are not related to diet-induced changes in insulin sensitivity. J Clin Endocrinol Metab 92: 2330-2335, 2007.

WAHRENBERG H, EK I, REYNISDOTTIR S, CARLSTROM K, BERGQVIST A, ARNER P: Divergent effects of weight reduction and oral anticonception treatment on adrenergic lipolysis regulation in obese women with the polycystic ovary syndrome. J Clin Endocrinol Metab 84: 2182-2187, 1999. 